\title{
Preface: Ostracoda: biostratigraphy and applied ecology
}

\author{
Dermeval A. Do Carmo • Ricardo L. Pinto • \\ Koen Martens
}

Published online: 15 March 2012

(C) Springer Science+Business Media B.V. 2012

The series of International Symposia on Ostracoda started in 1963, when ISO1 was organised in the historic Zoological Station of Naples by Dr Harbans Singh Puri. Matzke-Karasz et al. (2007) analysed the content of the 15 first ISO proceedings and grouped the 906 papers published in the various proceeding volumes (in stand-alone books and in journals) into several categories. Biostratigraphy and (palaeo-) ecology have always constituted strong components in this series of proceedings, and this inspired the organisers of the ISO16 to determine biostratigraphy and applied ecology as the main themes of their symposium.

The 16th International Symposium on Ostracoda was held in Brasilia, Brazil, between 26 and 30 July

Guest Editors: D. A. Do Carmo, R. L. Pinto \& K. Martens / Ostracoda - Biostratigraphy and Applied Ecology

D. A. Do Carmo · R. L. Pinto

Instituto de Geociências, Laboratório de

Micropaleontologia, Universidade de Brasília,

ICC_Ala Central, Subsolo ASS339/10, Campus

Universitário Darcy Ribeiro, Asa Norte, Brasília,

DF CEP 70910-900, Brazil

K. Martens ( $\square)$

Royal Belgian Institute of Natural Sciences, Freshwater

Biology, Vautierstraat 29, 1000 Brussels, Belgium

e-mail: martens@naturalsciences.be

K. Martens

Department of Biology, University of Ghent,

K.L. Ledeganckstraat 35, 9000 Ghent, Belgium
2009. The scientific communities from 25 different countries had representatives among the 107 participants, who brought to the meeting an amount of 102 contributions: 46 oral communications, 52 poster presentations and four keynote lectures given by invited speakers. The present proceedings volume comprises ten papers, a small selection of these contributions, and will serve as a legacy to the memory of this highly successful event. As always, the communication of scientific results is of prime importance, but the personal contacts with distant colleagues often leads to fertilisation of ideas and to successful collaborations. The ISO16 meeting scored on both accounts! Furthermore, by holding an ISO for the first time in South America, we hope to have helped foster ostracodology on this continent. In spite of the emphasis given in the current version of the symposium to biostratigraphy and applied ecology, contributions comprised also other research lines, such as Taxonomy, Morphology, Biogeography, Systematics and Evolution. In terms of geological time, the present proceedings contain six papers on Recent faunas, one on Tertiary, two on Mesozoic and one on Palaeozoic Ostracoda. The papers in this volume are loosely organised to follow this chronological sequence.

The volume opens with the paper by Decrouy et al. (this volume), who studied the Sediment Penetration Depth of epi- and infaunal ostracods in the Swiss Lake Geneva. The relevance of this paper is clear: ostracods have to moult 8-9 times during their development and each time have to calcify their valves using chemical 
components from the water. Valve chemistry is thus thought to reflect water chemistry at the time of moulting and is increasingly used to reconstruct past water chemistry and other environmental factors (salinity, temperature) to infer past climate change. Ostracods living on or in the sediments might thus live and moult in waters with different chemistry and this can significantly influence palaeoecological interpretations. It is thus important to know what determines the sediment penetration depth of living ostracods. Decrouy et al. (this volume) identified that apart from oxygen content of the pore waters, also grain size, water content itself and abundance of organic matter in sediment are controlling factors. Laurent Decrouy received the Sylvester Bradley Award for best oral presentation.

Pieri et al. (this volume) used recent non-marine ostracods as indicators of surface water quality, thus answering directly to the symposiums' second theme, applied ecology. They compared water quality with ostracod communities along a $21 \mathrm{~km}$ stretch of the Ledra River (NE Italy), and found that even in such a small spatial area, ostracod communities were sufficiently well differentiated to pick up minor impacts. In addition, spatial differentiation was consistent over time, which suggests that ostracod communities provide a time-integrated picture of water quality. They identified some potential indicator species, sensitive to anthropogenic discharges.

Külköylüoğlu et al. (this volume) analysed ostracod communities in Turkey and set out to identify drivers of community composition applying multivariate techniques on an impressive dataset of more than 140 localities in which many environmental variables were measured.

Higuti et al. (2007) were the first to indicate the importance of the root systems of indigenous floating plants (such as the water hyacinth, Eichhornia crassipes) as substrate for ostracod communities, especially in floodplains of large rivers, where megafloods of $6 \mathrm{~m}$ and more may turn sediments anoxic overnight. Liberto et al. (this volume) follow up on this pleuston idea, but this time in small and temporary ponds on an Argentinian island. A variety of factors appeared to determine density of ostracod communities in general and of individual species in particular.

From the same Valencia ostracod research group (Spain) comes the next contribution, this time on a special group of parasitic/commensal ostracods, the Entocytheridae. These occur on the gills of amphipods, isopods and crayfish, mostly in (eastern) North America, and in places also in (western) Europe. The present study of Aguilar-Alberola et al. (this volume) reports on the presence of an alien enthocytherid ostracod, Ankylocythere sinuosa (Rioja, 1942), on the American red swamp crayfish Procambarus clarkii (Girard, 1852), introduced into the Iberian peninsula for commercial purposes in 1973 and now common throughout much of Europe. This is a cautionary tale on how introduced species carry their own parasites and symbionts... Josep A. Aguilar-Alberola received the Sylvester Bradley Awards for best poster presentation jointly with Anna Baczewska (see below).

Pelagic Ostracoda can be a locally abundant component of the marine mesozooplankton, but the group remains poorly known. Baczewska et al. (this volume) contributed to their ecological characterisation and found that for one species salinity was correlated with distribution, whereas for another, latitude was the most important factor. Anna Baczewska received the Sylvester Bradley Awards for best poster presentation jointly with Josep A. Aguilar-Alberola (see above).

Warne \& Soutar (this volume) reconstructed Pliocene coastal palaeomorphology in southeast Australia, using Ostracoda as one of the proxies, mostly by distinguishing between stenohaline and euryhaline species. $\mathrm{Xi}$ et al. (this volume) reconstruct Chinese Late Cretaceous palaeoenvironments (lake levels, salinity) based on non-marine ostracod fossils from the palaeolake Songliao.

Darwinulidae have always been rather enigmatic animals, amongst other reasons because post-palaeozoic species all appear to be fully parthenogenetic (Martens et al., 2003). Recently, males of one recent species were described (Smith et al., 2006), but whether or not this nullifies the status of Darwinulidae as ancient asexuals is still highly debated (Martens \& Schön, 2008). Several recent darwinulids have been described since Rossetti \& Martens (1998) provided a taxonomical scheme with five genera in which the 30 or so recent species could be classified (see update and description of a sixth genus in Rossetti et al., 2011), and it has also been shown that at least some of the genera of recent darwinulids can also be recognised in the Mesozoic. Ballent ${ }^{(+)} \&$ Diaz (this volume) reassess the early Mesozoic species of the genus Penthesilenula from Argentina and described a new species.

Olempska (this volume) provided the only contribution on a Palaeozoic group, and maybe not even one 
of true Ostracoda, the Eridostracina. Ewa Olempska described the morphology and discussed the affinities of this remarkable group of small marine crustaceans with calcified carapaces and moult retention. She concluded that eridostracines belong within the lineage of Ostracoda, but that they might be a polyphyletic group, containing aberrant representatives, with ancestors probably among the conchoprimitid, leperditellid and beyrichioidean (ostracod) species.

During ISO 16, many other very worthwhile contributions have been presented, some of which have meanwhile been published elsewhere, for a variety of reasons, for example the tomographic work on giant sperm in cretaceous ostracods (MatzkeKarasz et al., 2009) and the further discovery of Palaeozoic ostracods with preserved soft parts (Siveter et al., 2010). This does not detract from the present proceedings volume, rather it demonstrates the value of the series of International Symposia on Ostracoda! We are happy to announce that the next ISO17 will be organised in Rome, in summer 2013. We can warmly recommend this meeting and invite you to attend!

Several people and organisations have supported ISO16. We thank the ISO16 Organizing Committee, the International Research Group on Ostracoda (IRGO), the Universidade de Brasília (UnB), Petróleo Brasileiro (PETROBRAS), the Coordenação de Aperfeiçoamento de Pessoal de Nível Superior (CAPES), the Associação dos Amigos do Museu de Geociências (AMGeo), the Brazilian Palaeontological Society and the National Agency for Petroleum, Gas and Biofuels (ANP).

\section{References}

Aguilar-Alberola, J. A., F. Mesquita-Joanes, S. Lopez, A. Mestre, J. C. Casanova, J. Rueda \& A. Ribas, this volume. An invaded invader: high prevalence of entocytherid ostracods on the red swamp crayfish Procambarus clarkii (Girard, 1852) in the Eastern Iberian Peninsula. Hydrobiologia. doi:10.1007/s10750-011-0660-1.

Baczewska, A., K. Blachowiak-Samolyk \& M. V. Angel, this volume. Distribution of pelagic Ostracoda (Crustacea) inhabiting the waters around Svalbard (Arctic Ocean: $76^{\circ} 36-81^{\circ} 50 \mathrm{~N}$ ). Hydrobiologia. doi:10.1007/s10750-011-0808-z.

Ballent, S. C \& A. R. Diaz, this volume. Contribution to the taxonomy, distribution and paleoecology of the early representatives of Penthesilenula Rossetti \& Martens, 1998 (Crustacea, Ostracoda, Darwinulidae) from Argentina, with the description of a new species. Hydrobiologia. doi:10.1007/s10750-011-0658-8.
Decrouy L., T. W. Venneman \& D. Ariztegui, this volume. Sediment penetration depths of epi- and infaunal ostracods from Lake Geneva (Switzerland). Hydrobiologia. doi: 10.1007/s10750-010-0561-8.

Higuti, J., L. F. Machado Velho, F. A. Lansac Tôha \& K. Martens, 2007. Pleuston communities are buffered from regional flood pulses: the example of ostracods in the Paraná River floodplain, Brazil. Freshwater Biology 52: 1930-1943.

Külköylüoğlu, O. \& N. Sari, this volume. Ecological characteristics of the freshwater Ostracoda in Bolu Region (Turkey). Hydrobiologia. doi:10.1007/s10750-010-0585-0.

Liberto, R., F. Mesquita-Joanes \& I. Cesar, this volume. Dynamics of pleustonic ostracod populations in small ponds on the Island of Martín García (Río de la Plata, Argentina). Hydrobiologia. doi:10.1007/s10750-011-0600-0.

Martens, K. \& I. Schön, 2008. Ancient asexuals: darwinulids not exposed! Nature 453: 587.

Martens, K., G. Rossetti \& D. J. Horne, 2003. How ancient are ancient asexuals? Proceedings of the Royal Society of London B 270: 723-729.

Matzke-Karasz, R., M. Schudack \& K. Martens, 2007. Preface. Hydrobiologia 585: 1-11.

Matzke-Karasz, R., R. J. Smith, R. Symonova, C. G. Miller \& P. Tafforeau, 2009. Sexual intercourse involving giant sperm in cretaceous ostracode. Science 324: 1535.

Olempska, E., this volume. Morphology and affinities of Eridostracina: Palaeozoic ostracods with moult retention. Hydrobiologia. doi:10.1007/s10750-011-0659-7.

Pieri, V., J. Vandekerkhove \& D. Goi, this volume. Ostracoda (Crustacea) as indicators for surface water quality: a case study from the Ledra River basin (NE Italy). Hydrobiologia. doi:10.1007/s10750-010-0568-1.

Rossetti, G. \& K. Martens, 1998. Taxonomic revision of the recent and Holocene representatives of the family Darwinulidae (Crustacea, Ostracoda), with a description of three new genera. Bulletin van het Koninklijk Belgisch Instituut voor Natuurwetenschappen, Biologie 68: 55-110.

Rossetti, G., R. I. Pinto \& K. Martens, 2011. Description of a new genus and two new species of Darwinulidae (Crustacea, Ostracoda), from Christmas Island (Indian Ocean) with some considerations on the morphological evolution in ancient asexuals. Belgian Journal of Zoology 141(2): 55-74.

Siveter, D. J., D. E. G. Briggs, D. J. Siveter \& M. D. Sutton, 2010. An exceptionally preserved myodocopid ostracod from the Silurian of Herefordshire, UK. Proceedings of the Royal Society of London B 277: 1539-1544.

Smith, R., T. Kamiya \& D. J. Horne, 2006. Living males of the 'ancient asexual' Darwinulidae (Ostracoda: Crustacea). Proceedings of the Royal Society of London B 273: 1569-1578.

Warne, M.T. \& B. Soutar, this volume. Pliocene coastal palaeomorphology and ostracod faunas of the Bass Strait hinterland, southeast Australia. Hydrobiologia. doi:10.1007/ s10750-011-0777-2.

Xi, D., S. Li, X. Wan, X. Jing, Q. Huang, J.-P. Colin, Z. Wang \& $\mathrm{W}$. $\mathrm{Si}$, this volume. Late Cretaceous biostratigraphy and paleoenvironmental reconstruction based on nonmarine ostracodes from well SK1 (south), Songliao Basin, northeast China. Hydrobiologia. doi:10.1007/s10750-0110765-6. 